\title{
Discussion of Military Theory Courses Examination Form and Content in Universities
}

\author{
Lei Zhang ${ }^{1, a}$ \\ ${ }^{1}$ Beihua University, Institute of Physical Education, China \\ a332145540@qq.com
}

\begin{abstract}
Keywords: Military theory; Examination form; Modern national defense; Innovation ability
\end{abstract}
\begin{abstract}
The military theory teaching in colleges and universities is well adapted to the needs of the development of the new military revolution. It is an important task for the military theory teaching reform in universities to train high-quality talents with modern national defense consciousness. Based on the needs of the new military revolution and the modernization of national defense, the disadvantages of the examination of military theory course were pointed out on the basis of a brief description of the teaching aim. The new idea of military theory course examination is put forward from examination content, examination form and performance evaluation.
\end{abstract}

\section{Introduction}

Since 1985, the Ministry of education has carried out military training programs for college students in some universities, and many schools have incorporated military theory into the teaching plan. Meanwhile, the military education in universities is gradually improving. With the rapid development of biotechnology, information technology and other advanced technologies, weapons, armies and wars have undergone fundamental changes. The new military revolution, which dissolves knowledge into national defense construction in various forms, is beginning to emerge.

\section{The Purpose of Military Theory Teaching}

In 1996, when general secretary Jiang Zemin met four presidents and secretaries of Jiaotong University, he pointed out:" our education work must solve two important problems: first, education should fully meet the needs of all kinds of talents in the modernization drive; second, education should comprehensively improve the quality and efficiency of running schools. " The guidance of General Secretary Jiang is not only the guiding principle of higher education reform, but the guiding ideology of military education in Colleges and universities. Colleges and universities need to train all kinds of talents needed for modernization, including military personnel. This has important implications for training personnel for the new century.

National defense education in Colleges and universities is not only an important part of moral education in Colleges and universities, but an important part of campus spiritual civilization construction. Carrying out national defense education among college students can stimulate the patriotic enthusiasm of young students and help them establish lofty ideals. The organizational discipline of college students has been cultivated, their comprehensive quality and concept of national defense has been enhanced. This promotes the all-round development of morality, intelligence and body. Military universities have particular emphasis on the cultivation of military personnel. Military academies and schools have taken advantage of their military theory and strategic thinking in order to cultivate commanders who master modern science and technology. Ordinary universities take the advantages of a complete range of disciplines, a strong teaching faculty, and a high level of scientific research, so as to cultivate military science and technology personnel.

\section{Disadvantages of the Examination Form and Content of the Current Military Theory Course}

The content of the course of military theory is a story of modern history in China according to the content of Ideological and political work, situation and policy education course. Its teaching aims to enable students to 
establish a simple concept of national defense in peace time and "national rise and fall, each with responsibility" and other simple national defense concepts.

It is Not Conducive to the Cultivation of Innovation Ability. "Innovation" is the soul of national survival and development. In each course teaching, the cultivation of innovative ability should be considered. When the students' innovative ability and spirit are cultivated, the teaching quality of universities will be improved. Nowadays, the teaching system is required to be perfected in the military theory teaching in universities. The evaluation indexes of the course examination must be judged according to the standard answer. "What to say, what to hear, what to remember, what to test" becomes a magic weapon for students to learn military theory course". As long as students follow this law, they can get high marks which is not conducive to guiding students to develop their thinking and innovation, combining military theory with professional knowledge.

It is Not conducive to the Formation of Modern National Defense Consciousness. The standard of modern national defense depends not only on the index of the strength of the army, such as technology, equipment, command and control, and compilation, but on the psychological quality and ability of the personnel. The vast majority of universities use the unified editorial "military theory" teaching materials at present, so that in the process of teaching students professional characteristics are ignored. The examination content which is limited to book knowledge focuses on military basic theory and the examination form generally adopts a single test paper answer. Therefore, this can not guide students to establish a modern national defense awareness compatible with modern science and technology in the space of thinking. The strategic thinking of "building the army nd strengthening the army by science and technology " is hard to establish among college students.

\section{The Examination Form and Content of the Military Theory Class Should be Improved.}

Examination, as the final link of teaching, is the process of checking whether the teaching achieves the purpose of teaching and checking the students' mastery and application of the knowledge they have learned. Therefore, the examination of military theory course should consider the content and form of examination according to the requirements of its teaching aim, and promote the teaching quality of military theory course through examination. We believe that the following measures are helpful to embody the teaching purpose of military theory course.

The Content of the Examination is the Combination of Theoretical Knowledge and Practical Ability. It focuses more on the principle of theoretical knowledge. Theory and practice are complementary and mutually reinforcing. Theoretical knowledge is the basis of practice and innovation. Practice is a flexible application of theoretical knowledge and a carrier of innovation. Without a solid theoretical knowledge, dazed practice is "flight of the air". Without extensive and in-depth practice, learning theory is "passive water". Therefore, the content of military theory course examination should follow the principle of combining theoretical knowledge with practical ability and taking theoretical knowledge as the main principle.

The "theoretical knowledge" mentioned here is not only the military basic knowledge such as military thought, but also includes the students' professional knowledge. The theoretical knowledge mentioned here not only includes military basic knowledge, such as military thought, but students' professional knowledge. The examination of theoretical knowledge requires students to finish it independently and flexibly within the stipulated time. On the one hand, we can check the students' knowledge of military basic knowledge; on the other hand, we can examine the students' ability to use professional knowledge. The teacher guides and inspires the students to combine the military theory knowledge with the professional knowledge, which further excavates the students' potential abilities.

"Practical ability" mainly refers to the ability of students to apply theoretical knowledge. The test of practical ability can be carried out by virtual reality simulation training method. With the continuous development and improvement of information and network technology, the possibility of virtual reality simulation training test has already been achieved. Students can choose virtual reality simulation training test questions according to their professional knowledge, and test the ability, which is safe and economical.

The Form of Test Questions Follows the Combination of Subjective and Objective Questions. It focuses more on the principles of subjective questions. Subjective questions test the ability of students to use 
what they have learned, in the form of questions, essays and so on. Students can combine the international military situation, the development trend of military high-tech and other issues to elaborate their views and ideas. The objective questions test students' mastery of basic knowledge, basic theory, mainly to fill in the blanks, choice, judgment, short form.

The combination of subjective and objective questions not only examines students' memory and understanding of military theoretical knowledge, but also students' practical ability. The main purpose of focusing on subjective problems is to give full play to the students' subjective initiative, so that they can evaluate and analyze the objective things, learn to transcend the current situation of things, and rationally predict the trend of things.

\section{Examination Results Follow the Usual Results and Assessment Results Combined.}

This is more emphasis on the usual score principle. Peacetime performance refers to the participation of military knowledge in campus cultural activities during the period of military theory teaching and non teaching. The usual results of military theory during teaching can be evaluated by answering questions and completing assignments. The usual results of participating in campus cultural activities involving military theory can be assessed by participation rate and the role of activities in activities. With the deepening of the teaching reform of military theory, the form, means and ways of military education are diversified. Writing class paper will become a way to test students' comprehensive application ability, which has been widely used. At that time, the average score is mainly based on the level of class papers, which is the most ideal.

Examination results refer to the examination of students' basic knowledge and basic theory in the form of examination paper at the end of military theory teaching. Sometimes the assessment results can not truly reflect the students' psychological quality and ability, which is not compatible with the teaching purpose. The usual results can examine students' psychological quality and ability from different levels, angles and aspects. Therefore, the usual results and the combination of examinations, focusing on the usual performance is worth learning. In teaching arrangements, military theory courses can be carried out in the first semester of the university. The examination results can be evaluated in the second or third year of college.

\section{Summary}

In conclusion, we must take the military theory of learning as an important content in the national defense education of college students in order to make college students understand military knowledge and the law of war, predict the future characteristics of war. The examination form and content of military theory course should study and explore the form, content and performance evaluation system of military theory examination according to the teaching purpose in order to improve the teaching level of military theory.

\section{References}

[1] Y. Gao and D.L Sun: Contemporary Education Research and Teaching Practice, (2017) No.6, p.57. (In Chinese)

[2] X.L Dai: Modern Education Science, (2019) No.1, p.82. (In Chinese)

[3] R. Liu: Journal of Inner Mongolia University for Nationalities (Social Sciences), Vol. 40 (2014) No.5, p.123. (In Chinese)

[4] S.L Chen: Reform \& Openning, (2009) No.8, p.148. (In Chinese)

[5] S.Q Gong: Journal of Hefei University of Technology (Social Sciences), Vol. 22 (2008) No.1, p.102. (In Chinese)

[6] B.T Peng and W. Wei: Education Modernization, (2017) No.6, p.135. (In Chinese)

[7] S.Y Hua and X.X Zhou: Vocational Education for Mechanical Industry, (2015) No.11, p.52. (In Chinese)

[8] W.L Xiong: Study on Problems and countermeasures of military theory teaching of general institutes of higher education (MS., Southwestern University, China 2012), p.37. (In Chinese)

[9] Z.P Zhu: Science and Technology, Vo1.811 (2016) No.19, p.195. (In Chinese) 
[10] Y.T Cen: Journal of Changsha University of Science and Technology(Social Science), Vo1.32 (2017) No.5, p.138. (In Chinese) 